\title{
Preparing Teachers to Become Lifelong Learners: Exploring the Use of Fiction to Develop Multiliteracies and Critical Thinking
}

\author{
PATRICIA A. GOUTHRO \\ Mount Saint Vincent University, Canada
}

SUSAN M. HOLLOWAY

University of Windsor, Canada

\begin{abstract}
Drawing upon research from a SSHRC grant entitled Creating a Canadian "Voice": Lifelong Learning, the Craft of Fiction Writing, and Citizenship, we examine how multiliteracies and critical thinking can be fostered using a framework of lifelong learning for teachers. We provide examples from authors and key informants who discuss learning and fiction writing to argue that there are benefits for diverse learners in using wider, more inclusive definitions of literacy associated with multiliteracies. We also provide examples of how multimodal technologies can foster learning connected to critical thinking and multiliteracies.
\end{abstract}

\section{Introduction}

Critical educators believe that the purpose of schooling is not just to prepare students for the workplace, but to prepare them for life. But how do we encourage teachers in our K-12 school system to think critically about their work as educators in preparing youth and adults to meet the challenges of a world shaped by the changing forces of globalization and emerging technologies? This paper explores how Faculties of Education (or as is the case in some universities, Schools or Departments of Education) can foster a lifelong learning framework to support the development of critical thinking and multiple literacies among preservice students in Teacher Education programs and graduate education students in Faculties of Education (who might also currently be working in the school system as teachers). The goal of this paper is to challenge the compartmentalization of academic teaching and research practices in Education that frequently isolate preservice teaching from graduate studies, and detach adult education/lifelong learning from teacher education. Incorporating a critical lifelong learning and multiliteracies framework in Faculties of Education may provide opportunities for student engagement that integrate a wide array of communicative approaches to learning. Drawing upon research from a current Social Science and Humanities Research Council (SSHRC) grant entitled Creating a Canadian "Voice": Lifelong Learning, the Craft of Fiction Writing, and Citizenship, this paper explores connections between lifelong learning and multiliteracies by examining how fiction writing in particular may be used to foster creative and critical learning experiences.

The paper begins with an explanation of the interconnections between lifelong learning and multiliteracies, followed by an elaboration of each of these research areas and their relevance to teacher education. We then provide a short discussion of the

Language and Literacy $\quad$ Volume 15, Issue 3, Special Issue 2013


changing nature of employment conditions for preservice teacher candidates as a rationale for broadening the focus of programs in Faculties of Education to incorporate a lifelong learning perspective. This is followed by an overview of the research study and an elaboration of the connections between lifelong learning, citizenship, and the craft of writing fiction. We define fiction writing in this study as works of imaginary prose that include novels and short stories, as well as many forms of children's literature. We then discuss two themes emerging from the findings related to how fiction writing can be connected to lifelong learning and multiliteracies to inform teacher education. These are: a) citizenship and diversity and b) creative pedagogies. We conclude by considering the overarching implications of critically-informed lifelong learning and multiliteracies approaches in Faculties of Education that draw upon fiction writing genres.

\section{Lifelong Learning, Multiliteracies and Teacher Education}

As two professors in Faculties of Education at different universities in Canada (Patricia is at Mount Saint Vincent University in Halifax, and Susan is at the University of Windsor in Ontario), we take a critical stance in our approach to education. Susan works in teacher education, at both the graduate and preservice level. Patricia works in Graduate Studies in Lifelong Learning. The field of lifelong learning, although it encompasses learning across the lifespan, concentrates primarily on adult education. In fact, the terms lifelong learning and adult education are often used somewhat interchangeably in the field-lifelong learning is often the language of policy, particularly in the United Kingdom (UK) and Australia, while adult education describes the historical, critical roots of practice, and is also the term more commonly used in the United States (US). While some of the graduate students in the graduate program at Patricia's university are school-based educators (particularly if they work in leadership roles in schools), most students work in adult learning settings such as college instruction, adult English as an Additional Language (EAL) programs, community literacy, human resource development, or the military. In 2013/2014, however, Patricia will be teaching a new course in Lifelong Learning in a Bachelor of Education (B.Ed.) program.

Our SSHRC grant in lifelong learning, citizenship, and fiction writing stimulated our interest in the links between teacher education, lifelong learning, and multiliteracies. As we detail in the methodology section below, the present study is based upon life history interviews with fiction authors, as well as shorter interviews with key informantsindividuals working in initiatives and programs in support of fiction writing. Among both groups of research participants were people with experience as educators in various lifelong learning contexts including formal schooling and adult writing instruction in community-based programs. As we reviewed our interview data we also realized that a number of the participants were involved in projects that used a multiliteracies approach. In ensuing conversations, we reflected that multiliteracies projects already happening in schools and documented through research (Gallagher \& Ntelioglou, 2011; Marshall \& Toohey, 2010; Taylor, Bernhard, Garg, \& Cummins, 2008) are energizing for both students and educators because they offer opportunities for creative and critical engagement. In reviewing our data we realized that these same attributes describe the multiliteracies projects discussed by participants in our study. We also feel that fiction itself is still an underexplored modality within multiliteracies - that is, as fiction relates 
to other modes such as drama, poetry, visual arts - often in ways that transcend what fiction on its own might accomplish. In the spirit of bridging various areas of research and practice that are usually in isolation from one another, we argue that fiction writing, as one component of multiliteracies pedagogies, offers a small piece of the puzzle of how teacher education programs can engage preservice and graduate Education students in imaginative teaching practices.

Before elaborating the literature in the fields of lifelong learning, multiliteracies, and teacher education that informs this paper, we provide a rationale for drawing together these seemingly disparate fields of practice by looking at four points of intersection; a) critical approaches to learning, b) communication and language, c) creative pedagogies, and d) learning and citizenship.

\section{Critical Approaches to Learning}

As critical educators we understand that power permeates all learning discourses. Using multimodalities or engaging in lifelong learning does not necessarily mean that an educator is taking a critical approach to learning. However, there is a strong tradition of radical adult education that infuses critical discourses in lifelong learning with a social purpose focus (Bamber \& Crowther, 2012; Schuetze, 2006). The literature on multiliteracies has evolved within a framework that emphasizes the importance of social justice and equity (Danzak, 2011; Schmidt, 2011). Both lifelong learning and multiliteracies discourses draw upon the work of critical theorists such as Freire, Giroux, Foucault, and hooks. We see an overlap in how multiliteracies and lifelong learning may inform a critical approach to both preservice and graduate Education programs.

\section{Communication and Language}

The capacity for human beings to communicate and learn through language is a topic of central concern to many critical adult educators and multiliteracies educators. In their study on teaching community educators, Bamber \& Crowther (2012) argue that, "Habermas's ideas about communicative rationality can inform thinking about the practical knowledge needed by students in dealing with uncertain situations" (p. 186). In his discussion of multiliteracies, Schmidt (2011) considers the use of electronic blackboards to take up difficult topics such as race, assessing how online discussions can become "a site for critical debate" (p. 36). The emphasis upon exploring how language and communication shape teaching and learning experiences is central to these research and practice discourses.

\section{Creative Pedagogies}

Like K-12 teachers working from a multiliteracies perspective, adult educators working within lifelong learning frameworks recognize that learning can occur in many different contexts. There is an openness to exploring alternative and creative pedagogical opportunities whilst recognizing the importance of diverse meaning making practices and genres. Lifelong learning has a history of drawing upon creative and arts-based forms of inquiry to explore feminist, social justice, and inclusion themes (Butterwick \& Dawson, 2005; Clover, 2010; Grace \& Wells, 2007; Selkrig, 2011). Likewise, pedagogical approaches in multiliteracies may include artistic applications, as

\begin{tabular}{lll}
\hline \hline Language and Literacy & Volume 15, Issue 3, Special Issue $2013 \quad$ Page 52
\end{tabular}


demonstrated in Danzak's (2011) study in which EAL teens depict immigrant experiences through graphic novels. Similar to research in multiliteracies (Ajayi, 2011; Williams, 2009; Gee \& Levine, 2009), lifelong learning research and practice increasingly engages with popular culture, social media, and new technologies as important sites for learning (Redmon Wright \& Sandlin, 2009; Tisdell, 2007). Both critical lifelong learning and multiliteracies pedagogies draw upon artistic, technological, and cultural resources to develop innovative and creative approaches to teaching and learning.

\section{Learning and Citizenship}

Critical adult educators argue that lifelong learning is intricately linked with democracy (Brookfield, 2005). Within the context of globalization, citizenship is an increasingly complex and differentiated experience affected by issues such as gender (English, 2006) and ethnicity (Guo, 2006). Or, as multiliteracies researchers Cope and Kalantzis (2009) put it,

With these new communication practices [iPods, wikis, etc.], new literacies have emerged. They are embodied in new social practices - ways of working in new or transformed forms of employment, new ways of participating as a citizen in public spaces, and even perhaps new forms of identity and personality. (p. 167)

Professors teaching in Faculties of Education play an important role in preparing current and future teachers to attain both the skills and the philosophical understandings to engage critically with issues of diversity, globalization, and citizenship. Ultimately, teachers and their students are citizens. What they learn or do not learn informs how they will live their lives and influence those around them. At stake, as Martha Nussbaum (2010) argues, is the very heart of world democracies if we forget the need for higher education to teach students to lead an examined life and to be capable of argumentation that imagines and sympathizes with a range of perspectives.

There is the potential for a culture of ethical problematizing and compassionate imagining of social justice in every discipline. If we are to prepare teachers to educate their students to participate actively as citizens, this requires that they work through difficult and conflicting ethical considerations, such as what they think is right and fair, and what will promote genuine democratic processes. For example, Luce-Kapler, Sumara \& Iftody (2010) consider the role of teachers in fostering ethical approaches to engaging with New Literacies, recognizing that the blurring between real-life people and fictional characters in media and in on-line environments with which their students engage outside of school creates new challenges and opportunities for educators. Williams (2009) argues that the creation of Web 2.0, which offers more interactive opportunities for participant engagement, also requires ongoing reflective debate about the implications for democratic learning and citizen involvement.

The foregoing suggests the potential to bring together adult education and lifelong learning, multiliteracies and teacher education in support of an approach to teacher education more reflective of the needs of twenty-first century learning. Such an 
approach can bridge academia and communities, using technology contextualized in social milieus to forge pedagogies of socio-political awareness as well as critical thinking. These ideas are elaborated in the section below as we discuss in more detail the theoretical links between the research and practice streams of lifelong learning, multiliteracies and teacher education.

\section{Lifelong Learning}

Lifelong learning can be understood as a philosophical concept, a field of research and practice, and as an area of policy in education research. Centeno (2011) points out that the concept of lifelong learning "has become not only one of the most studied subjects in the field of education but also a recurring topic in policy and entrepreneurial discourse" (p. 133). Philosophically, the concept of lifelong learning has been debated primarily in literature in adult education, where most of the research and exploration of practice has been carried out. The recent UK report on The Future of Lifelong Learning (Schuller \& Watson, 2009) argues that it is insufficient to think of learning only in terms of formal schooling. Lifelong learning also includes non-formal contexts (structured but not necessarily credentialed programs or courses), and informal contexts (learning in the everyday). Selkrig (2011) explains, "lifelong learning implies that learning consists of a ubiquity of experiences for an individual across his or her life" (p. 578). Starting a graduate degree, participating in a workshop on retirement planning, and exchanging teaching tips in a hallway are examples of lifelong learning engagements.

Since the 1970s, organizations such as UNESCO have supported lifelong learning as an important component in creating a more socially just and equitable world. "Learning must be in association with all dimensions of life, conceived and expressed as lifelong, life-wide, and life-deep" (Duke \& Hinzen, 2012, p. 19). Critical adult educators argue that society relies upon lifelong learning not only for economic prosperity, but also for social prosperity in well-being, health, personal growth, and social connectivity (Field, 2009). Similarly, critical and feminist perspectives on lifelong learning acknowledge the value of learning in many realms, not only in the paid workplace, but also within the homeplace and civil society (Field, 2010; Gouthro, 2009; Guo, 2006; Torres, 2011).

Lifelong learning is a contested concept, however. Critical adult educators argue that neoliberal influences have increasingly co-opted lifelong learning by developing policies and programs that give primacy to learning connected to the perceived needs of the marketplace (Bowl \& Tobias, 2012; Olssen, 2006). Murphy (2000) claims the rhetoric of globalization spurs changes in policy that devolve government responsibilities for educational supports for its citizens and presents lifelong learning as a neutral response for learners to adapt to technological advances. Hinchliffe (2006) argues that, "the key driver of the development of lifelong learning [through government policies] is thus the emergence of the knowledge economy in an era of globalization" (p. 94) and its requisite that learners can adapt to continuous change.

As a consequence, Grace (2007) argues that, "in Canada, current federal learningand-work policy is focused on individual learner worker development and an iteration of lifelong learning involving a regimen of cyclical training throughout one's work life" (p. 85). Rather than serving as a liberating opportunity, lifelong learning becomes a wheel in

\begin{tabular}{lll}
\hline Language and Literacy & Volume 15, Issue 3, Special Issue 2013 & Page 54
\end{tabular}


a hamster's cage: adult learners are running to catch up, but never get further ahead. Instead, there is further polarization between the haves and have-nots, while socialstructural inequalities such as gender differences in expectations remain unchallenged (Fenwick, 2004; Gouthro, 2009). Troubling these notions of how lifelong learning should be construed, critical, feminist, and post-modern educators raise questions that challenge the limitations on education imposed by what Habermas (1984) discusses as instrumental or technical approaches to rationality that favour a more simplistic meansend approach to guide decision-making. Edwards (2006) argues that we need to question the contexts in which lifelong learning can occur, recognizing that it is not a neatly bounded nor easily understood process. A critical approach to lifelong learning contests the ways in which dominant neoliberal discourses may constrain more emancipatory understandings to lifelong learning (Holloway \& Gouthro, 2011; Olssen, 2006).

Teacher education programs similarly need to challenge a neoliberal approach to schooling. By engaging teacher candidates and graduate students in theoretical discussions and practical implementations of lifelong learning from a critical perspective, they are more likely themselves to question the inequities inherent in a neoliberal vision of how educational institutes should be designed and run. Further, as we argue below, rather than simply delivering subject-based content, teacher education utilizing a multiliteracies pedagogy switches the lens to examine how institutions construct knowledge in particular ways. Multiliteracies pedagogies help to defamiliarize hegemonic norms and calls into question power relations.

\section{Multiliteracies}

Engagement with critical and multiliteracies includes, but also extends beyond the ability to manage the mechanics of reading and writing. A focus on mechanics "obscures the multiple ways in which literacy interrelates with the workings of power" (Gee, 1996, p. 46). Luke (2004) argues, "one of the characteristics of neo-liberal educational policy is the fostering of counter-aesthetic, anti-intellectual, and uncritical training.....and a more general focus on instrumental knowledge and technique" (p. 94). Many people still refer to Faculties of Education as "Teachers' College”, which implies a narrow perception of these institutions as merely training facilities. As critical educators, we believe lifelong learning and multiliteracies can resituate Faculties of Education as places where relevant and current socio-cultural issues and discourses about power, language, and equity are discussed. While there is significant research on the value of multiliteriacies pedagogies (Alvermann, 2009; Rowsell, McLean, \& Hamilton, 2012) in teacher education, our slant is somewhat different in that our goal is to also highlight the importance and complementary vision of lifelong learning. Moreover, we believe that a focus on fiction writing offers another means to explore multiliteracies pedagogies in practice.

Seminal research in the field of multiliteracies began with the work of writers such as Street (1984) who defines literacy as social practice. The New London Group, a self-named group composed of the following theorists, Cazden, Cope, Cook, Fairclough, Gee, Kalantzis, Kress, Luke, A., Luke, C., Michaels, Nakata, (1994, 2000) later coined the term multiliteracies which refers to the dialogic nature of texts that juxtapose multimodalities of print, technology, semiotics, orality, and visual arts. They argue 
cultural and linguistic diversity also play a key role in shaping literacy concepts and practices. Thus, the New London Group reason that people who do not have access to mainstream literacy in societies hit a glass ceiling, limiting opportunities for work and promotion (Cope \& Kalantzis, 2009, p. 170). In addition to their critique of existing social orders, the New London Group (Cazden, Cope, Cook, Fairclough, Gee, Kalantzis, Kress, Luke, A., Luke, C., Michaels, Nakata, 2000) argue that multiliteracies pedagogies play a role in envisioning creative forces to shape the future design of our world in using the aesthetics of art (including creative writing) as a form of counter-hegemony.

Multiliteracies educators recognize that literacy influences every sphere of life and contributes to learning around citizenship and inclusion. For instance, Kendrick and Jones (2008) explore Ugandan girls' literacy practices through drawing and photography as visual modes of literacy to gain insight into gender equity issues in that country. Interpreting drawings by primary school girls, they note, "By making visible what is hidden in their mind's eye, these girls reveal who they imagine they are allowed to become in this society" (p. 386). Rowsell, McLean, \& Hamilton's (2012) study of a grade nine classroom explores multiliteracies through rich visual literacy practices whereby the image of a tattoo, for instance, can lead to discussions of body art and cultural norms, identity, and the medical implications of tattooing; "images are suspended in webs of meanings, and one reason that they are valuable is that it is possible to trace threads of meaning from elements in the images that can be used in the curriculum" (p. 446). These studies provide examples for preservice and graduate students to think through what multiliteracies pedagogies can look like in their own classrooms. In a similar vein, our study also examines how multiliteracies explore identity and representation through multimodality by giving practical examples linked to fiction writing.

A multiliteracies framework also investigates the construction of meaning in cyberspace, what Gee (1996) terms a "plural set of social practices" (p. 46). A focus of multiliteracies research is understanding how technology affects communication, representation, and meaning making. Most of the research and exploration of how multiliteracies can be incorporated in education has been taken up in studies with older youth and teacher education contexts. For example, Alvermann (2009) explores how teens' knowledge and skills of gaming and texting can be connected to other learning in schools, thus revamping traditional school curricula. Cope and Kalantzis (2009, p. 172) argue that multimedia, such as video games, position youth as actors and agents, rather than as spectators or audiences. However, they also ask, "to what extent are the new media that engage user agency (such as games) providing an escape from reality instead of a preparation for it?" (p. 173).

Focusing on technology-mediated writing assessments, Cope, Kalantzis, McCarthey, Vojak, and Kline (2011) posit that "evolving technologies, applied to the discursive and social relations of new writing spaces on the Internet, provide us for the first time with a paradigm-changing opportunity" (p. 81). These researchers envision students of all ages working in teams to create multimodal projects by accessing a range of sources on the web. Literacy is understood here as experiential forms of communication (for example, to be a scientist, students use diagrams and lab hypotheses to learn, rather than focusing on what are often extraneous questions that are prevalent on 
standardized tests such as the 5W's: who, what, when, where, and why. In the future, Cope, Kalantzis, McCarthey, Vojak, and Kline (2011) envision that students' multimodal productions will undergo continuous formative assessment using new technologies, eventually replacing the need for summative or high stakes evaluation.

While some schools or individual teachers embrace multiliteracies, many still rely heavily on print literacy. Alternatively, schools might dabble with technology, but as a purely "add-on" function; for example, 75 minute lectures accompanied by PowerPoint presentations that only use print to represent meaning. The heuristic impulse of learning in relation to technology gets lost if teachers do not understand the philosophical underpinnings of multiliteracies.

With respect to multiliteracies in community and adult learning settings, Goodfellow (2011) analyzes the ways in which digital literacies can be fostered through a critical multiliteracies perspective in higher education. Morgan, Cuskelly \& Moni (2011) discuss the merits of a multiliteracies perspective in understanding the learning processes of adults with intellectual disabilities. The use of photography has been explored by Fowler (2008) in assessing literacy practices in Further Education (FE) in the UK, and a study by Nimmon \& Begoray (2008) considers how photonovels can help teach English as an additional language to mature women learners.

Dolan (2012) notes that teacher education and lifelong learning, with few exceptions, have evolved as separate discourses, yet both lifelong learning and multiliteracies offer potentially beneficial insights to inform a critical approach to teacher education. Like critical adult educators, Cope and Kalantzis (2009) argue that, "in a pedagogy of multiliteracies, all forms of representation, including language, should be regarded as dynamic processes of transformation rather than processes of reproduction" (p. 175). For those of us who teach in Faculties of Education, we need to be committed to strategies to carefully prepare and support teachers to use both critical lifelong learning and multiliteracies approaches in their own teaching practices.

\section{Broadening the Focus of Teacher Education}

While recognizing that the goal of teacher education programs is to prepare teachers to work in the $\mathrm{K}-12$ school system, there are practical reasons to consider how teacher education programs may broaden their focus to incorporate a lifelong learning as well as a multiliteracies perspective. Although teacher shortages exist in some rural and northern parts of Canada (Kitchenham \& Chasteauneuf, 2010), Van Nuland (2011) points out that there is a surplus of B.Ed. graduates unable to find work where they would like to live. As she observes, graduates often have to work part-time or move to new communities to secure teaching jobs. An article in the Toronto Star notes that many B.Ed. graduates work as substitute teachers for years before securing full-time employment (Rushowy, 2012).

As Van Nuland (2011) notes, B.Ed. graduates need to consider "turning to other areas for livelihood" (p. 416). As professors in Faculties of Education, we have seen numerous B.Ed. and graduate students in education secure educated-related employment outside the school system in areas such as the Information Technology (IT) industry, adult EAL instruction, or as community college instructors. In our universities some teacher education students do practicum placements in community-based sites rather 
than in K-12 schools. As Van Nuland (2011) observes, "Some faculties allow candidates other practicum choices, which may include international schools, alternative schools, First Nation cultural centres, libraries, literacy programs, museum programs, teaching studies (art, dance, defence, exercise)" (p. 414). Further, Ryan, Carrington, Selva \& Healy (2009) discuss a preservice teacher education program in Australia in which students are required to do a placement in a community context in addition to their Education courses and $\mathrm{K}-12$ classroom practicum. They argue this better prepares them to work in diverse learning settings: "Students need to experience the often contradictory workings of pedagogical knowledge and political motivation in different community contexts, so that they are better prepared for the complexity of enacting their skills and knowledge in their work as educators" (p. 157).

As a consequence, some Education faculties are considering how they might incorporate an adult learning and lifelong learning framework into B.Ed programs to prepare their teacher graduates for a broader repertoire of educational practice, and faculty members who work in the areas of adult education or lifelong learning are beginning to contribute to B.Ed. programs. At Susan's university, even where there is currently no adult education or lifelong learning degree program, she observes that a number of Education students do not intend to teach in K-12 schools but instead plan to use the acquired teaching skills in adult learning contexts such as hospitals, public libraries, or businesses. These students want to do their degrees locally because of commitments to family and/or work, and they prefer to attend in-person classes instead of taking a degree in adult education via distance online learning options. They believe a degree in Education will help them become educators and leaders in their other chosen fields.

Lifelong learning and multiliteracies approaches may also respond to some of the complexities in educational practice experienced by students working in global and internationalized contexts. Guo \& Chase (2011) note that in recent years there has been a significant increase in international student enrolments in Canadian universities. In addition, as faculty charged with the responsibility of preparing students to develop as educators we note that many of them are dealing with the effects of globalization in different ways. We see teachers working with EAL and Newcomer students here in Canada, teachers who travel abroad to teach, international graduate students who return to their country of origin to teach, and domestic teacher educators working with cohorts of international students. Since many students must negotiate hybrid identities, they may appreciate a public space (the teacher education classroom) to analyze and share the complexities of their lived experiences. Transferring skills from one context to another (for example, different countries or workplaces) involves critical thinking and imaginative vision, which needs to be fostered in all Education students.

As critical educators, we believe there is mutual advantage to Canadian-born, firstgeneration, and International students sharing their unique knowledge and experiences with each other and with us, the faculty. Many of our international students return to their countries to work in education or other professional contexts. In addition, after they graduate, many Canadian students of education go abroad to teach English as an Additional Language (EAL) courses in universities or take advantage of opportunities to work in international schools. As Coulter and Abney (2009) argue, "this can offer

\begin{tabular}{|c|c|}
\hline Language and Literacy & Volume 15, Issue 3, Special Issue 2013 \\
\hline
\end{tabular}


teachers a depth of experience that would be difficult to achieve by working in schools in their country of origin" (p. 110). Globalized experiences are now part of the structural fabric of Faculties of Education. Multiliteracies pedagogies and critical approaches to lifelong learning provide a theoretical framework to make sense of these developments and help teachers conceptualize learning in diverse contexts.

Given the changing complexity of societies and workplaces, individuals need to engage in learning across the lifespan. Yet, it is unlikely that school teachers will foster this capacity for their own students to become critical lifelong learners unless they also understand and identify with this philosophy. Both lifelong learning and multiliteracies offer strategies and insights that educators may be able to use in whatever context they work in to develop critical teaching practices.

\section{Overview of the Research Study}

This Social Science and Humanities Research Council of Canada (SSHRC) grant explores connections between citizenship, lifelong learning, and the craft of writing fiction. We selected interview participants through a purposeful sampling strategy, which Patton (2002) describes as "selecting information-rich cases whose study will illuminate the questions" (p. 230) which are central to the research project. Using a life history/biographical approach, we interviewed over thirty Canadian recognized and emerging published fiction writers working in the genres of children's/young adult literature; mystery (crime fiction) or literary prose. We used these categories to set parameters for selection. In actuality, many authors write in more than one genre; for example, in poetry as well as prose, children's books as well as academic texts.

We also interviewed several authors from the United States and the United Kingdom for cross-cultural comparative purposes. In addition, we interviewed more than twenty key informants-individuals in the policy, publishing, educational and writing sectors-in order to gain insights into the policies, educational programs, and supports that exist for learning connected to fiction writing. We sought to include diverse representation from the authors in terms of geographic region, age, ethnicity, sexual orientation and gender.

The interviews with the authors were what Scheibelhofer (2008) describes as problem-centered in that they combined a narrative life history approach with a focus on a particular concern-in this instance, how it was that our informants learned to become writers. The interviews were conducted in person and were between one and two hours in length and topics included authors' education and learning experiences (including writing courses or workshops) that led to their development as writers, as well as their family background and personal motivations.

The interviews with key informants were also face-to-face and lasted about fortyfive minutes. Questions focused upon their experiences of various types of writing programs. Both authors and key informants were asked about government financial support for their work, the role of emerging technologies and changes in the publishing world. The interviews were transcribed and returned to participants, with the invitation to make revisions and edits. Charmaz (2005) notes that, "coding is the first step in taking an analytic stance toward the data" (p. 517). We began our thematic analysis using a coding scheme based upon the interview guiding questions. As we reviewed and compared the 
data, further themes and categories emerged. For example, although none of the participants used the language of multiliteracies to describe their work, we interpreted that many of their projects could be framed as examples of multiliteracies-this is a strong theme that emerged from our study and is elaborated in the following section.

\section{Findings}

The interviews reveal a number of examples of lifelong learning opportunities connected to multiliteracies approaches to fiction writing. Our intention in sharing these examples is to provide insights into the benefits of using a multiliteracies approach within a broader lifelong learning context that is connected with fiction writing. These ideas may then be drawn upon to consider critical approaches to enhance teacher education. Through our analysis we strive to adhere to participants' views and representations of their work and we have organized the findings into two thematic areas: citizenship and diversity and creative pedagogies. Of course, coding is not always neat or precise, so readers will notice overlaps in the category themes.

\section{Citizenship and Diversity}

Some writers that we interviewed provide interesting insights into teaching experiences related to fiction writing that address issues of diversity with a Canadian national context. These examples illustrate ways of engaging learners in topics connected to citizenship.

One participant, literary writer Daphne Marlatt, offers an example of one of her projects that exemplifies many of the qualities of multiliteracies. In Steveston Recollected (1975), Marlatt created a unique textual representation of the oral histories of people living in the fishing village of Steveston, British Columbia. She captures oral histories that might otherwise have been lost as she draws attention to the Japanese Internment camps at Stevenson in World War II. Marlatt works with a translator to record the oral histories of Japanese-Canadian fishermen. She recalls:

The interviews had been done in Japanese by a young woman, Maya Koizumi, who had emigrated here from Japan and discovered that the language that was being spoken in Steveston was a dated form of Japanese. People had started coming over from Wakayama to fish as early as the 1890s...Maya also got access to some early documents about the Japanese Canadian fishing union and the early strikes, and translated those (interview, March 8, 2011).

Marlatt wrote a second book entitled Steveston (2001) which she describes as follows: "It's a book of long-line poems about that community and its history, together with Robert [Minden]'s black-and-white photographs, mostly portraits of people he met on the street" (interview, March 8, 2011). These kinds of texts illuminate clear examples of what it is to engage in multiliteracies. These books about Steveston are politically engaged in bringing voice to a community historically disenfranchised, and are historically rooted and locally contextualized. Marlatt's book constructs meaning through a variety of artistic forms in relation to one another-union documents juxtaposed

\begin{tabular}{llc}
\hline \hline Language and Literacy & Volume 15, Issue 3, Special Issue 2013
\end{tabular}


with long-line poetry; archaic Japanese Canadian and Finnish languages written alongside Canadian English and fused into poetry; photography as a form of visual literacy. Marlatt's work is a counter- narrative that exemplifies the infusion of political critique with multimodalities. Her work relates to larger questions about colonization and the nation state within Canada. This is one example for teacher candidates of how they might use multimodal fiction writing texts in their own practice to raise with their students important issues pertaining to diversity and citizenship. This is also an effective way to combat stereotypes, as Marlatt's approach requires artistic synergy and careful attention to detail and analysis to contextualize experiences.

Fiction writing that consciously raises social issues is an effective tool to surface diversity and citizenship issues, as children's literature author and professor Peter Cumming explains with regard to his teaching strategy in the university:

When I'm teaching about childhood and Canadian culture, I really want them to know that they have diverse childhoods including recognizing their own experience in those ten blocks in Toronto, to certainly legitimate that. But it's also to realize that there are some very different experiences: rural versus urban; western versus eastern; north versus south; First Nations. There's such tremendous diversity in this country and I think it's the strength. My play Snowdreams is specifically about Canadian immigration, Canadian identity, Canadian identity building, working out the good and the bad of this very odd country (interview, August 30, 2010).

Cumming, in both his writing and teaching, reflects the heterogeneous possibilities for constructing Canadian identity. Children's literature author and elementary school teacher Gina McMurchy-Barber offers a further example of a multiliteracies project in which she engages young students in authentic learning. She describes her project as follows:

I have this archaeology degree and a background in journalism. One year, I wanted to teach the kids about archaeology because I hated the idea of not having a place for it. So that summer the principal gave me permission to dig a big pit in the back of the school property. I spent the summer collecting objects from a little antique store, and I created a scenario: layers of stratigraphy. I created a volcanic eruption and a whole layer of ash so they'd have to go through the ash and figure out what had happened. I taught them techniques about excavation, how to record, and how to create a hypothesis based on the artifacts. (interview, March 8, 2011).

McMurchy-Barber prefaces this learning experience by sharing with the students a story she had written called Reading the Bones, which in 2008 became her first novel. She notes, "Reading the Bones was about teaching archeology, learning about who owns the past, resource management, and how we guard our prehistoric resources. There was a lot of learning opportunity in that story" (interview, March 8, 2011). Juxtaposing the 
experiences of reading historic fiction alongside an archaeological role-play deepens the learning experience. In the book, the skeletal remains (the bones to be read by the young protagonist, Peggy Henderson) come from the First Nations territory of the Coast Salish, located at one of their traditional settlements in Crescent Beach, British Columbia. This multiliteracies project uses emotional, social, and intellectual engagement to foster a deeper understanding of specific, local, historical events. It also raises critical questions that are integral to citizenship and lifelong learning discourses such as "What is historical fact?" "Which epistemologies count?" and "How are national identities socially constructed?"

\section{Creative Pedagogies}

Creative writers pursue new ways of naming, viewing, and perceiving the world. They conceptualize and observe the world in minute detail, often with startling clarity. Through their own prose and artistic endeavors, they demonstrate how to construct meaning through multiple forms of literacy. Their playfulness and acumen within their own writing and pedagogical practices can nourish educators' own practices as they draw upon multiliteracies pedagogies to encourage their teacher candidates to think in broader lifelong learning contexts. Mystery writer Garry Ryan, who has a background in teaching high school explains:

I taught kids. They learned a lot of the skills that they needed through creative writing. It didn't necessarily have to be a formal essay. And I think the research backs that up. It's about a familiarity with writing, clarifying your message. It's not the five-paragraph essay that necessarily teaches you how to write. Although it's one way of writing; it's not the only way (interview, May 28, 2010).

Creative writing, as Ryan points out, teaches students how to articulate ideas, a skill that can be transferred to critical writing. Children's book author and education professor Kari-Lynn Winters uses a cross-curricular approach to her teaching:

Drama and literacy mesh very nicely as we know from the book by David Booth and other people: Dorothy Heathcote and Cecily O'Neill. We've known that for a long time. So I do a lot of meshing. My drama classes are not theatre classes; they are drama classes, which means I focus on how can we use the art of theatre or the art of drama to better math, or better literacy, or whatever (interview, February 11, 2011).

From these different educators we can see how a multiliteracies pedagogy can provide creative opportunities for engaging students in learning within the hybrid spaces of real-life and fictional themes. American mystery writer and professor Cathy Pickens developed a course called Developing Your Creative Process for the MBA (Masters of Business Administration) program in her university. This program exposes students to multiple art forms and requires them to complete an art project. As Pickens explains: 
They paint, or they go to a wood working shop and they do something physical, and at the same time they talk to someone who is passionate about what they do and is gifted in that area. Then they select an extended project of their own to do with a mentor. A lot of them come back and say that it was the most transforming thing that they've done; for some it just doesn't work. It depends on what you put into it. More than seventy-five percent of them, which I consider a passing grade for myself, will come away from that and look at their work and their life in a different way (interview, May 1, 2011).

Probably most of the students in this MBA program were surprised to find an arts-based course within their curriculum. Yet, intellectual growth, integral to lifelong learning, often requires the expansion of the imagination. Even when an experience is daunting, uncomfortable, or upsetting, and despite the sense of personal risk and challenge involved, there is value in students experiencing exciting new ways of thinking and engaging in the world.

Key informant Chris Leslie is part of a learning team that develops programs and curricula for the nationally funded Scottish Book Trust. This organization is a model of policy into practice that views fiction authors as an important resource for developing what Leslie refers to as "creative literacy." They support Authors Live, which are live webcasts that feature contemporary writers on the BBC (British Broadcasting Corporation), and the Scottish Children's Book Awards, whereby Scottish children vote for their preferred choice among a shortlist of children's books. Connected to these events, the Scottish Children's Book Trust coordinates visits by writers to schools across the country and produces learning resources to accompany these events. Read-It, another program of the Scottish Children's Book Trust is "basically aimed at increasing young people's engagement with reading and writing through the use of digital storytelling, specifically through book trailers." As Leslie elaborates:

In order to make a trailer they had to understand the atmosphere of the book and find a way to convey that. We made sure they were accountable for their decision-making and asked them, 'Why did you put that shot there?' 'Why did you pick that photograph or video?' 'Why did you use that transition?' 'Why have you structured the trailer in this way?' We didn't just want them throwing things together, and we found that it was necessary to put a strong emphasis on critical decision making because they were making a lot of autonomous decisions. They really wanted their trailers to be as good as they possibly could be and were paying attention to the atmosphere and how they could portray characters, impact on audience, structure and things like that. All of those things, to me, are what would be addressed in a formal paper and that's what we really needed to see. (interview, June 29, 2012)

Furthermore, Leslie observes the project seems to work well with students of diverse socio-economic backgrounds. Teachers are part of the consultations in the creation of all 
these resources. By incorporating visual literacy, the reading and composition of graphic novels build skill and knowledge capacities in students. Leslie quotes a phrase from a teacher who was commissioned by the Scottish Book Trust to develop some tutorial web videos: "it's all about creating something new out of something learned" (interview, June 29, 2012).

\section{Discussion and Conclusion}

We provide these examples of how fiction writing can inform teaching practices to contribute to the ongoing dialogue in Canada about what multiliteracies pedagogies might look like in practice for teachers wanting to move from multiliteracies theory to practice. Like teacher educators working from a multiliteracies perspective, critical adult educators believe that learning should pursue emancipatory and inclusive goals, challenging the narrowness of a neoliberal agenda that suggests education should be oriented primarily to work-related skills.

The type of education, both initial and ongoing, that educators provide, will influence if and how students in Faculties of Education become critically reflective educators, whether they work in $\mathrm{K}-12$ schools or other education contexts. We envision teachers who are critical lifelong learners, who are engaged in multiliteracies, and who are able to prepare their own students to deal with challenges they will need to address both in the workplace and as Canadian citizens. Multiliteracies and lifelong learning approaches are important when combined to promote an engaged, democratic citizenry, where all people in our diverse population feel they have the right, the access, the means, and the ability to participate in matters that pertain to their communities and the larger nation.

Fiction genres have the potential to support a critical approach to lifelong learning and multiliteracies, taking teacher education beyond narrow skills-based approaches to reflect the increasingly diverse and globalized new generation of teachers. A multiliteracies pedagogy gives educators innovative ways to think through how traditional literary studies can be revamped without losing the depth of critical perspectives. Cope and Kalantzis (2009) observe that we are "in the midst of a profound shift in the balance of agency" (p. 172) in which people are more apt to be the protagonists and creators rather than the audience and readers. They give the example of video games as a narrative in which youth "are content with being no less than actors rather than audiences" (p. 173). Similarly, fiction may offer opportunities for individuals to creatively engage in learning. A multiliteracies pedagogy gives educators a powerful way to develop curriculum wherein students exercise agency from within the imaginative, critical choices they are able to make in their own learning. In this way, a multiliteracies pedagogy coupled with a lifelong learning approach can provide the basis for a teacher education program that meets the needs of twenty-first century learners, broadens teachers' skills and experience to include adult and community learning settings, and enhances a critical approach to citizenship. 


\section{References}

Alvermann, D. E. (2009). Sociocultural constructions of adolescence and young people's literacies. In L. Christenbury, R. Bomer, P. Smagorinsky (Eds.), Handbook of adolescent literacy research (p.p. 14-28). New York: The Guilford Press.

Ajayi, L. (2011). A multiliteracies pedagogy: Exploring semiotic possibilities of a Disney video in a third grade diverse classroom. Urban Review, 43(3), 396-413.

Bamber, J. \& Crowther J. (2012). Speaking Habermas to Gramsci: Implications for the vocational preparation of community educators. Studies in Philosophy and Education, 31(2), 183-197.

Bowl, M. \& Tobias, R. (2012). Learning from the past, organizing for the future: adult and community education in Aoteara New Zealand. Adult Education Quarterly, 62(3), 272-286.

Brookfield, S. D. (2005). The power of critical theory: Liberating adult learning and teaching. San Francisco: Jossey-Bass.

Butterwick, S. \& Dawson, J. (2005). Adult education and the arts. In T. Fenwick, T. Nesbit, \& B. Spencer (Eds.), Contexts of adult education: Canadian perspectives, (pp. 281-289). Toronto: Thompson.

Cazden, C., Cope, B, Cook, J., Fairclough, N., Gee, J., Kalantzis, M., Kress, G., Luke, A., Luke, C., Michaels, S., Nakata, M. (The New London Group). (1994). A pedagogy of mulitliteracies: Designing social futures. Harvard Educational Review, 66(1), 60-94.

Centeno, V. (2011). Lifelong learning: A policy concept with a long past but a short history. International Journal of Lifelong Education, 30(2), 133-150.

Clover, D. E. (2010). A contemporary review of feminist aesthetic practices in selective adult education journals and conference proceedings. Adult Education Quarterly, 60(3), 233-248.

Charmaz, K. (2005). Grounded theory in the $21^{\text {st }}$ century: Applications for advancing social justice studies. In Denzin, N.K. \& Lincoln, Y.S. (Eds) The Sage Handbook of Qualitative Research, $3^{\text {rd }}$ Ed. (507-535). Thousand Oaks, CA: Sage.

Cope, B. \& Kalantzis, M. (2009). "Multiliteracies": New literacies, new learning. Pedagogies: An International Journal, 4(3), 164-195.

Cope, B. \& Kalantzis, M. (Eds.). (2000). Multiliteracies: Literacy learning and the design of social futures. London and New York: Routledge.

Cope, B., Kalantzis, M., McCarthey, S., Vojak, C., \& Kline, S. (2011). Technologymediated writing assessments: Principles and processes. Computers and Compositions 28, 79-96.

Coulter, M. A. \& Abney, P. C. (2009). A Study of Burnout in International and Country of Origin Teachers. International Review of Education, 55, 105-121.

Danzak, R. L. (2011). Defining identities through multiliteracies: EL teens narrate their immigration experiences as graphic stories. Journal of Adolescent and Adult Literacy, 55(3), 187-196.

Dolan, A. M. (2012). Reforming teacher education in the context of lifelong learning: The case of the B.Ed. programme in Ireland. European Journal of Teacher Education,35(4), 463-479.

Duke, C. \& Hinzen, H. (2012). Adult education and lifelong learning within 
UNESCO: CONFITEA, Education for all, and Beyond. Adult Learning, 22/23 (4/1) 18-23.

Edwards, R. (2006). Beyond the moorland? Contextualizing lifelong learning. Studies in the Education of Adults, 38(1), pp. 25-36.

English, L. (2006). A Foucauldian reading of learning in feminist, nonprofit organizations. Adult Education Quarterly, 5(2), 85-101.

Fenwick, T. (2004). What happens to the girls? Gender, work and learning in Canada's 'new economy'. Gender and Education, 16(2), pp. 169-185.

Field, J. (2009). Well-being and happiness. IFLL Thematic Paper 4.

Field, J. (2010). Making the good society work. Adults Learning, 21(10), 24-27.

Fowler, Z. (2008). Negotiating the textuality of further education: Issues of agency and participation. Oxford Review of Education, 34(4), 425-441.

Gallagher, K. \& Ntelioglou, B.Y. (2011). Which new literacies? Dialogic and performance in youth writing. Journal of Adolescent \& Adult Literacy, 54(5), 322-330.

Gee, J. P. (1996). Social linguistics and literacies: Ideology in discourses $\left(2^{\text {nd }}\right.$ ed.). London: Taylor \& Francis.

Gee, J. P. \& Levine, M. H. (2009). Welcome to our virtual worlds. Educational Leadership, 66(6), 48-52.

Goodfellow, R. (2011). Literacy, literacies and the digital in higher education. Teaching in Higher Education, 16(1), 131-144.

Gouthro, P. A. (2009). Neoliberalism, lifelong learning and the homeplace: Problematizing the boundaries of 'public' and 'private' to explore women's learning experiences. Studies in Continuing Education, 31(2), 157-172.

Grace, A. P. (2007). Envisioning a critical social pedagogy of learning and work in a contemporary culture of cyclical lifelong learning. Studies in Continuing Education, 29(1), 85-103.

Grace, A. P. \& Wells, K. (2007). Using Freirean pedagogy of just ire to inform critical social learning in arts-informed community education for sexual minorities. Adult Education Quarterly, 57(2), 95-114.

Guo, S. (2006). Adult education for social change: The role of a grassroots organization in Canada. Convergence, 39(4), 107-122.

Guo, S. \& Chase, M. (2011). Internationalisation of higher education: integrating international students into Canadian academic environment. Teaching in Higher Education, 16(3), 305-318.

Habermas, J. (1984). The theory of communicative action: Volume two. Reason and the Rationalization of Society. (T. McCarthy, Trans.). Boston: Beacon. (Original work published in German in 1981).

Hinchliffe, G. (2006). Rethinking Lifelong Learning. Studies in Philosophy and Education, 25, 93-109.

Holloway \& Gouthro (2011). Teaching resistant novice educators to be critically reflective. Discourse: Studies in the Cultural Politics of Education, 32(1), 29-41.

Kendrick, M. \& Jones, S. (2008). Girls' visual representations of literacy in a rural Ugandan community. Canadian Journal of Education, 31(2), 371-404.

Kitchenham, A. \& Chasteauneuf, C. (2010). Teacher supply and demand: issues in 
northern Canada. Canadian Journal of Education, 33(4), 869-896.

Luce-Kapler, R., Sumara, D. \& Iftody, T. (2010). Teaching ethical know-how in new 1Literary spaces. Journal of Adolescent and Adult Literacy, 53(7), 536-541.

Luke, A. (2004) At last: The trouble with English. Research in the Teaching of English, $39(1), 85-95$.

Marlatt, D. (1974, 1984, 2001). Steveston. 3rd ed. Vancouver: Ronsdale Press, 2001. With photographs by Robert Minden.

Marlatt, D. (Ed.) (1975). Steveston recollected: a Japanese-Canadian history. (Essays). Victoria: Aural History, Provincial Archives of British Columbia.

Marshall, E. \& Toohey, K. (2010). Representing family: Community funds of knowledge, bilingualism, and multimodality. Harvard Education Review, 80(2), 221-241.

McMurchy-Barber (2008). Reading the bones. Toronto, Ontario: Dundurn Press.

Morgan, M. F., Cuskelly, M., \& Moni, K. B. (2011). Broadening the conceptualization of literacy in the lives of adults with intellectual disabilities. Research \& Practice for Persons with Severe Disabilities, 36(3/4) 112-120.

Murphy, M. (2000). Adult education, lifelong learning and the end of political economy. Studies in the Education of Adults, 32(2), 166-181.

Nimmon, L. \& Begoray, D. (2008). Creating participatory photonovels: A classroom guide. Adult Basic Education \& Literacy Journal, 2(3), 174-178.

Nussbaum, M. (2010). Not for profit: Why democracy needs the humanities. Princeton: Princeton University Press.

Olssen, M. (2006). Understanding the mechanisms of neoliberal control: lifelong learning, flexibility, and knowledge. International Journal of Lifelong Education, 25(3), 213-230.

Patton, M. Q. (2002). Qualitative Research and Evaluation Methods, $3^{\text {rd }}$ Ed. Thousand Oaks, California: Sage Publications.

Redmon Wright, R. \& Sandlin, J. (2009). Cult TV, hip hop, shape-shifters and vampire slayers: A review of the literature at the intersection of adult education and popular culture. Adult Education Quarterly, 59(2), 118-141.

Rowsell, J., McLean, C., \& Hamilton, M. (2012). Visual literacy as a classroom approach. Journal of Adolescent \& Adult Literacy, 55(5), 444-447.

Rushowy, K. (2012/03/22) Ontario to increase teacher training to two years. Toronto Star. http://www.thestar.com

Ryan, M., Carrington, S., Selva, G. \& Healy, A. (2009). Taking a 'reality' check: expanding pre-service teachers' views on pedagogy and diversity. Asia-Pacific Journal of Teacher Education, 37(2), 155-173.

Scheibelhofer, E. (2008) Combining narration-based interviews with topical interviews: methodological reflections on research practices. International Journal of Social Research Methodology, 11(5), 403-416.

Schmidt, T. T. (2011). "Subjectivities-in-process": Writing race and the online discussion board. Radical Teacher, 90, 36-46.

Schuetze, H. G. (2006). International concepts and agendas of lifelong learning. A Journal Of Comparative Education, 36(3), 289-306. 
Schuller, T. \& Watson, D. (2009). Learning through life: Inquiry into the future of lifelong learning. Leicester: NIACE.

Selkrig, M. (2011). Learning about ourselves from others: transformation of artists' identities through community-based arts practice. International Journal of Lifelong Education, 30(5), 577-589.

Street, B. (1984). Literacy in theory and practice. Cambridge: Cambridge University Press.

Taylor, L. K., Bernhard, J. K. Garg, S., Cummins, J. (2008). Affirming plural belonging: building on students' family based cultural and linguistic capital through multiliteracies pedagogy. Journal of Early Childhood Literacy, 8(3), 269-294.

Tisdell, E.J. (2007). Popular culture and critical media literacy in adult education: theory and practice. New Directions for Adult and Continuing Education, 115, 5-13.

Torres, C. A. (2011). Dancing on the deck of the Titanic? Adult education, the nationstate and new social movements. International Review of Education, 57(1/2), 2955.

Van Nuland, S. (2011). Teacher education in Canada. Journal of Education for Teaching: International Research and Pedagogy, 37(4), 409-421.

Williams, P. (2009). Technology literacy: a multiliteracies approach to democracy. International Journal of Technology and Design Education, 19(3), 237-254.

\section{Author Biographies}

Patricia A. Gouthro is a Professor in the Faculty of Education at Mount Saint Vincent University in Halifax, Nova Scotia. Her research focuses on lifelong learning, citizenship, and fiction writing. She has served as President for the Canadian Association for the Study of Adult Education and as a co-editor for the International Journal of Lifelong Education.

Susan M. Holloway is an Associate Professor in the Faculty of Education at the University of Windsor in Ontario. Her research focuses on critical literacy, multiliteracies, poststructural and feminist theories. She currently teaches English Methodology, Second Language Acquisition theories, and Approaches to Literacy Development. 